УДК 614.23:617:378.14].003.13

\title{
ШЛЯХИ ПІДВИЩЕННЯ ЕФЕКТИВНОСТІ НАВЧАННЯ ЛІКАРІВ-ІНТЕРНІВ ЗІ СПЕЦІАЛЬНОСТІ "ХІРУРГІЯ" НА ОЧНОМУ ЦИКЛІ ІНТЕРНАТУРИ
}

\author{
Б. О. Матвійчук, В. С. Заремба, В. Т. Бочар, О. Б. Матвійчук, І. М. Павловський, \\ Ю. Й. Голик, Н. Р. Федчишин, А. Д. Квіт, А. Р. Стасишин \\ Львівський начіональний медичний університет імені Данила Галицького
}

\section{WAYS TO IMPOVE THE TRAINING OF INTERNS IN THE SPECIALITY "SURGERY" ON A FULL-TIME INTERNSHIP CYCLE}

\author{
B. O. Matviychuk, V. S. Zaremba, V. T. Bochar, O. B. Matviychuk, I. M. Pavlovskyi, \\ Yu. Y. Holyk, N. R. Fedchyshyn,A. D. Kvit,A. R. Stasyshyn \\ Lviv National Medical University by Danylo Halytsky
}

\begin{abstract}
3 метою підвищення ефективності підготовки інтернів зі спеціальності “Хірургія” на очному циклі інтернатури, окрім практичного навчання, вважаємо доцільним більш ширше залучення їх до наукової праці, шляхом систематичного реферування сучасної наукової літератури, збору клінічного матеріалу та публікації статей у фахових хірургічних журналах. При наявності декількох різних за профілем клінічних баз для всебічного та якісного навчання молодого лікаряхірурга під час навчання в очній частині інтернатури рекомендуємо проводити місячну ротацію інтернів між цими базами.

With purpose to improve the training of interns in the speciality "Surgery" on a full-time internship cycle, in addition to practical training, we consider appropriate to involve interns into scientifical work more widely. This includes regular analysis of up-to-date scientific literature, gathering of clinical material and publishing articles in professional journals. In case of availability of several clinical bases, we find monthly rotation of interns between them to be highly useful.
\end{abstract}

Вступ. Інтернатура (первинна спеціалізація) $є$ обов'язковою формою післядипломної підготовки випускників усіх факультетів вищих медичних закладів освіти III-IV рівнів акредитації незалежно від підпорядкування та форми власності, після закінчення якої їм присвоюється кваліфікація лікаря-спеціаліста 3 певного фаху [1]. Інтернатура проводиться у формі очно-заочного навчання на кафедрах вищих медичних закладів освіти III-IV рівнів акредитації і закладів післядипломної освіти та стажування в базових установах охорони здоров'я $[2,3]$.

Основними завданнями інтернатури 3 хірургії $є$ поглиблене вивчення та вдосконалення знань про клініку, діагностику, методи консервативного та операційного лікування хірургічних захворювань, оволодіння і засвоєння практичних навичок, маніпуляцій та операційних втручань, професійна підготовка молодих спеціалістів до подальшої самостійної практичної діяльності.

Основна частина. Кафедрою хірургії та ендоскопії ФПДО Львівського національного медичного університету імені Данила Галицького спільно із працівни-

() Б. О. Матвійчук, В. С. Заремба, В. Т. Бочар, та ін. ками опорної кафедри хірургії та проктології Національної медичної академії післядипломної освіти ім. П. Л. Шупика, кафедрами хірургії Дніпропетровської медичної академії та Запорізької медичної академії післядипломної освіти у 2006 р. розпрацьовано типовий навчальний план та уніфіковану програму інтернатури зі спеціальності “Хірургія”, затверджені МO3 України [4]. Згідно з типовим навчальним планом підготовки інтерна-хірурга впродовж трирічного (33 місяці) періоду передбачено 12 місяців або 1872 год навчання на кафедрі і суміжних кафедрах - щорічно по 4 міс. (624 год) та 21 місяць або 3276 год навчання на базах стажування - щорічно по 7 міс. (1092 год) (табл. 1).

Підготовку інтернів на кафедрі хірургії та ендоскопії ФПДО Львівського національного медичного університету імені Данила Галицького проводимо згідно 3 Робочою навчальною програмою, складеною на підставі вказаних типового навчального плану та уніфікованої програми у 2006 р. та скорегованої-у 2012 р.

Впродовж навчання інтернів на профільній кафедрі читаємо лекції, проводимо практичні та семінарські заняття. Для кращого засвоєння матеріалу кафедра у 2012 р. видала методичні рекомендації з практич- 
Таблиця 1. Графік навчального процесу лікарів-інтернів зі спеціальності “Хірургія” на кафедрі хірургії та ендоскопії ФПДО ЛНМУ імені Данила Галицького

\begin{tabular}{|c|c|c|c|c|c|c|c|c|c|c|c|c|}
\hline Рік навчання & \multicolumn{10}{|c|}{ Місяці } \\
\hline & VIII & IX & X & XI & XII & I & II & III & IV & V & VI & VII \\
\hline Перший & Б & К & К & К & К & Б & Б & Б & Б & Б & Б & В \\
\hline Другий & Б & Б & Б & Б & Б & К & К & К & К & Б & Б & В \\
\hline Третій & Б & Б & Б & Б & Б & Б & Б & К & К & К & К & \\
\hline
\end{tabular}

Примітки: Б - навчання на базі стажування (заочна частина інтернатури);

К - навчання на кафедрі (очна частина інтернатури);

В - відпустка.

них і семінарських занять на кожен рік інтернатури. До семінарських занять інтерни готують коротку мультимедійну презентацію, після доповіді якої разом із викладачем проводиться наукова дискусія щодо проблем із відповідної теми. У кінці кожного тематичного розділу, згідно з календарним планом, передбачений підсумковий тестовий контроль знань.

У клініці всі інтерни мають по два обов'язкових 12-годинних чергування згідно з затвердженим графіком. Однак більшість молодих лікарів за власним бажанням чергує значно частіше. Щодня професор або доценти кафедри розписують лікарів-інтернів на планові операційні втручання. Під час ургентних чергувань, яких, до речі, основна клінічна база несе 18-20 разів на місяць, інтерни мають змогу оволодіти широким спектром невідкладної хірургічної допомоги. Також на кафедрі є можливість переглядати хід операційних втручань у режимі on-line. Власними коштами викладачів кафедри усі навчальні кімнати та аудиторії підключені до мережі “Інтернет”. Це дає змогу викладачам та інтернам спілкуватися 3 провідними клініками світу, брати участь у телеконференціях та майстер-класах $з$ хірургії.

Впродовж навчання в очній частині інтернатури на базі відділень лікарні швидкої медичної допомоги за кожним інтерном закріплюємо 1-2 палати. Під керівництвом викладачів та ординаторів молоді лікарі займаються курацією хворих цих палат, беруть участь в операційних втручаннях, перев'язках, доповідають на щотижневих загальних клінічних обходах, а інтерни третього року-і на клінічних розборах пацієнтів.

У клініці є обов'язковою участь інтернів у щотижневих та післяургентних клінічних обходах та розборах тематичних хворих, участь у лікарняних науковопрактичних і патологоанатомічних конференціях.

Впродовж останніх років кафедрою запроваджено реферування інтернами наукових публікацій. Щоранку, після лікарської конференції та здачі чергування, інтерни коротко (в межах 5 хвилин) доповідають пе- ред усіма лікарями клініки попередньо зареферовані ними найновіші статті із наукових вітчизняних та закордонних хірургічних журналів. За певним розділом хірургії закріплений практичний лікар або працівник кафедри, який рецензує відповідну наукову публікацію.

Після завершення кожного циклу очної частини навчання на кафедрі проводимо піврічну, а в кінці інтернатури - державну атестацію, яка проходить у три етапи. Перший етап - письмовий екзамен відповідно до розпрацьованих та затверджених на методичній комісії факультету екзаменаційних білетів. Кожен білет містить 5 теоретичних питань та одну ситуаційну задачу. На другому етапі перевіряємо практичні навики, які проводимо біля ліжка хворого, у перев'язочних, у навчальних аудиторіях. До цього етапу атестації входить перевірка засвоєння виконання основних хірургічних маніпуляцій, зокрема таких, як накладання швів, зав'язування вузлів, лапароскопічні маніпуляції на фантомах, виготовлених силами працівників кафедри. Третій етап заключної атестації інтернів проводимо у вигляді усної індивідуальної доповіді-дискусії перед атестаційною комісією. Окрім того, в кінці інтернатури (3-й рік) проводимо науковопрактичну конференцію. Після експертної оцінки у її програму включаємо роботи, виконані на високому науково-методичному рівні. Наукову основу доповідей складає переважно опрацювання архівного матеріалу хірургічних відділень. Нововведення кафедри - доповіді інтернів після корекції асистентами та доцентами мають продовження у наукових публікаціях у фахових хірургічних журналах із обов'язковим включенням у співавтори інтернів, які працювали 3 даної тематики. Такий підхід, по-перше, навчає молодих спеціалістів працювати із документацією, медичною статистикою; по-друге, стимулює їх займатись наукою; по-третє, дає можливість починати свою самостійну практичну діяльність вже із певним науковим доробком, що тепер особливо акту- 
ально у зв’ язку з новими підходами до присвоєння кваліфікаційних категорій.

Після закінчення терміну підготовки в інтернатурі та успішного проходження державної атестації лікарямінтернам присвоюється звання лікаря-спеціаліста зі спеціальності “Хірургія” та видається сертифікат.

Під час навчання в очному циклі ми запровадили місячну ротацію інтернів по різних клінічних базах. Кафедра хірургії та ендоскопії ФПДО Львівського національного медичного університету імені Данила Галицького проводить навчальний процес на чотирьох клінічних базах. Основною базою, де проходять навчання більшість інтернів, а також слухачі курсів передатестаційних циклів та циклів тематичного удосконалення, є Комунальна міська клінічна лікарня швидкої медичної допомоги. Це великий багатопрофільний лікувальний заклад, розрахований на 930 ліжок, з них 570 є хірургічного профілю. У лікарні є 18 клінічних відділень, 3 яких 12 - хірургічного профілю (у тому числі 3 хірургічні, 2 гінекологічні, 2 травматологічні, урологічне, нейрохірургічне, офтальмологічне, відділення щелепно-лицевої хірургіi), та 14 параклінічних (в тому числі ендоскопічне, рентгенологічне, трансфузіологічне відділення, відділення комп'ютерної томографії, ультрасонографіï, інтервенційної радіології, функціональної діагностики, гіпербаричної оксигенації, клініко-діагностична лабораторія та цілодобовий травмпункт). До складу клініки хірургії та ендоскопії ФПДО входять два відділення - перше і третє хірургічні. Окрім того, на базі 1-го хірургічного відділення організовано міський центр лікування постраждалих із торакоабомінальною травмою, на базі 3-го хірургічного відділення - міський центр лікування хворих із шлунково-кишковими кровотечами. Багатопрофільність лікарні дає можливість кожному інтерну у вільний від практичних та семінарських занять час бути присутнім, а також асистувати не тільки на хірургічних, але й на гінекологічних, урологічних, травматологічних та нейрохірургічних операціях.
Другою клінічною базою інтернів є 3-тє хірургічне відділення Львівської обласної лікарні. Це відділення єдине в області, де, окрім лікування загальної хірургічної патологіï, надається допомога хворим із ендокринними захворюваннями, зокрема, із хворобами щитоподібної та прищитоподібної залоз, підшлункової залози, надниркових залоз, які потребують хірургічного втручання.

Третьою клінічною базою проходження інтернатури є Перша міська клінічна лікарня ім. Князя Лева. На базі хірургічного відділення лікарні працює міський судинний центр і центр “Діабетична стопа", де проходять лікування хворі із ускладненнями цукрового діабету, які мають гнійно-некротичні ураження нижніх кінцівок.

Четвертою клінічною базою проходження інтернатури є ендоскопічне відділення Львівського обласного клінічного діагностичного центру.

Усі бази клініки забезпечені новітньою діагностично-лікувальною апаратурою, в тому числі широко впроваджено сучасні малоінвазійні технології.

Ротація груп інтернів дає можливість ознайомити ïx впродовж навчання майже із всіма основними хірургічними захворюваннями та їх діагностикою, методами консервативного та операційного лікування, навчитися працювати в умовах як ургентної, так і планової хірургіi.

Висновки: 1. 3 метою підвищення ефективності підготовки інтернів зі спеціальності “Хірургія" на очному циклі інтернатури, окрім практичного навчання, вважаємо доцільним більш ширше залучення їх до наукової праці, шляхом систематичного реферування сучасної наукової літератури, збору клінічного матеріалу та публікації статей у фахових хірургічних журналах.

2. При наявності декількох різних за профілем клінічних баз для всебічного та якісного навчання молодого лікаря-хірурга під час навчання в очній частині інтернатури рекомендуємо проводити місячну ротацію інтернів між цими базами.

\section{Література}

1. Закон України “Про затвердження Положення про спеціалізацію (інтернатуру) випускників вищих медичних і фармацевтичних закладів освіти III-IV рівня акредитації медичних факультетів університетів” від 19.09.1996 р. №291 [Електронний ресурс]. - Режим доступу: www.zakon.rada.gov.ua/ laws/show/z0696-96

2. Поляченко Ю. В. Медична освіта у світі та в Україні: навч. посібник / В. Г. Передерій, О. П. Волосовець, В. Ф. Москаленко. - Київ : Книга-плюс, 2005. - 383 с.

3. Сучасний розвиток вищої медичної та фармацевтичної освіти й проблемні питання забезпечення якісної підготовки лікарів і провізорів / М. В. Банчук, О. П. Волосовець, I. I. Фещенко [та ін.] // Медична освіта. -2007.-№2.-C. 5-13.

4. Типовий навчальний план і програма спеціалізації (інтернатури) випускників вищих медичних навчальних закладів, медичних факультетів університетів зі спеціальності “Хірургія”. - Київ, 2006. - 44 с. 